\title{
上腕骨小頭骨折の治療経験
}

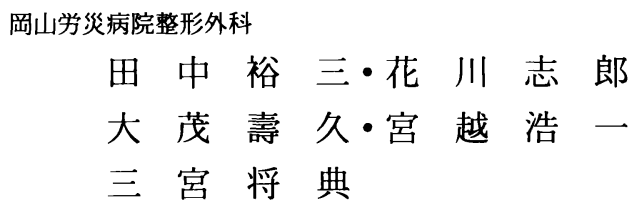

\section{Fracture of Capitulum Humeri}

by

\author{
Yuzo Tanaka, Shiro Hanakawa, Toshihisa Oshige, \\ Koichi Miyakoshi and Masanori Sannomiya \\ Department of Orthopaedic Surgery, Okayama Rosai Hospital
}

\begin{abstract}
Fracture of the capitulum humeri is rare, and opinions on the preferred surgical management of this injury differ. We studied 12 patients who underwent surgical treatment for fractures with a mean follow-up of 3 years ( 7 months to 10 years 3 months). In 11 cases, open reduction and internal fixation were performed, while in 1 case, the fracture fragment was removed. Kirschner wire and soft wire are used in our method for open reduction. Open reduction is stable and produces the best results, especially when performed immediately after the trauma. Early open reduction is thus recommended as the treatment for fracture of the capitulum humeri.
\end{abstract}

Key words : Capitulum（上腕骨小頭)，Humerus（上腕骨），Fracture（骨折）

はじめに

上腕骨小頭骨折は时関節周辺の骨折の中では極めて 稀であり，骨表面が軟骨で被われているため強固な内 固定が困難である. 我々は積極的に観血的整復内固定 術を行い良好な結果を得たので報告する。

\section{対象および方法}

1980 年より 1997 年までに当院にて治療を行った男 性 5 例, 女性 7 例の計 12 例 12 肢である. 手術時年齢 は 22 才から 63 才, 平均 51.2 才であった. 受傷機転 は，全例が転倒または転落によるものであった，患側 は右 5 例, 左 7 例. 調查期間は 7 ケ月から 10 年 3 ケ 月, 平均 3 年であった.

骨折型を $\mathrm{AO}$ 分類に従い, 骨軟骨のスライス状骨 片を B3-1-1 不全型, 小頭の単独骨折を B3-1-2 完全
型，骨片に滑車の一部を含む B3-1-3 滑車型，及び B31-4 粉碎型と 4 型に分類した。 それぞれ不全型が 3 例, 完全型が 4 例, 滑車型が 2 例, 粉硅型が 3 例であった. 手術までの期間は受傷 5 日以内のものが 7 例, $6 \sim 10$ 日以内のものが 2 例, 1 ケ月以上経過した陳旧例が 3 例であった．観血的整復内固定術（以下, ORIF と略 す）を施行した症例が 11 例で, 骨片切除例は 1 例の みであった。原則的に ORIF は小頭の前額面を Kirschner wire (以下, K-wire と略す) にて固定後, 矢状面を軟鋼線にて固定し行った（表 1 ）。合併症は 橈骨頭骨折 2 例, 橈骨 - 尺骨骨折 1 例, 时頭骨折 1 例 であった。

\section{結果}

成績は Grantham らの成績評価基準を使用し, 関 節可動域, 安定性, 疼痛を調べ評価した（表 2 ）. 
表 1 上腕骨小頭骨折の臨床成績

\begin{tabular}{|c|c|c|c|c|c|c|c|c|c|}
\hline 症例 & $\begin{array}{l}\text { 年齢 } \\
\text { (歳) }\end{array}$ & 性 & 骨折型 & $\begin{array}{l}\text { 手術までの } \\
\text { 期間（日） }\end{array}$ & 治療 & $\begin{array}{c}\text { ROM } \\
\text { (Ext. } / \text { Flex.) }\end{array}$ & Instability & Pain & Result \\
\hline 1 & 22 & 男 & B3-1-(1) & 5 & 軟鋼線 & $-3^{\circ} / 135^{\circ}$ & $5^{\circ}$ & Mild & Good \\
\hline 2 & 59 & 男 & B3-1-(1) & 0 & 軟鋼線 & $-5^{\circ} / 125^{\circ}$ & None & Mild & Good \\
\hline 3 & 44 & 女 & B3-1- (3) & 5 & $\mathrm{~K}$-wire+軟鋼線 & $0^{\circ} / 140^{\circ}$ & None & No & Excellent \\
\hline 4 & 45 & 男 & $\mathrm{B} 3-1-(1)$ & 0 & 骨片摘出 & $0^{\circ} / 140^{\circ}$ & None & No & Excellent \\
\hline 5 & 56 & 女 & B3-1- (2) & 4 & $\mathrm{~K}$-wire+軟鋼線 & $10^{\circ} / 135^{\circ}$ & None & No & Excellent \\
\hline 6 & 49 & 女 & B3-1- (4) & 0 & $\mathrm{~K}$-wire+軟鋼線 & $0^{\circ} / 140^{\circ}$ & None & No & Excellent \\
\hline 7 & 60 & 男 & B3-1-(2) & 88 & $\mathrm{~K}$-wire+軟鋼線 & $-15^{\circ} / 132^{\circ}$ & None & No & Good \\
\hline 8 & 49 & 女 & B3-1-(4) & 10 & $\mathrm{~K}$-wire+軟鋼線 & $-5^{\circ} / 110^{\circ}$ & None & Mild & Good \\
\hline 9 & 56 & 女 & B3-1- (2) & 4 & $\mathrm{~K}$-wire+軟鋼線 & $-30^{\circ} / 115^{\circ}$ & None & Mild & Fair \\
\hline 10 & 62 & 女 & B3-1-(4) & 7 & $\mathrm{~K}$-wire+軟鋼線 & $-27^{\circ} / 112^{\circ}$ & None & Mild & Fair \\
\hline 11 & 53 & 男 & B3-1-(3) & 51 & $\mathrm{~K}$-wire+軟鋼線 & $-43^{\circ} / 116^{\circ}$ & None & No & Fair \\
\hline 12 & 59 & 女 & B3-1-(2) & 65 & 軟鋼線 & $-40^{\circ} / 90^{\circ}$ & None & Mild & Poor \\
\hline
\end{tabular}

表 2 Grantham 評価

\begin{tabular}{cccc}
\hline \hline & Instability & Pain & ROM restriction \\
\hline Excellent & no & no & no \\
Good & $\leqq 10^{\circ}$ & mild & $\leqq 40^{\circ}$ \\
Fair & $10^{\circ}<$ inst $<15^{\circ}$ & moderate & $40^{\circ}<$ rest $<60^{\circ}$ \\
Poor & $15^{\circ} \leqq$ & severe & $60^{\circ} \leqq$ \\
\hline
\end{tabular}

表 3 Results related to timing

\begin{tabular}{lccccc}
\hline \hline & Excellent & Good & Fair & Poor & Total \\
\hline 5 日以内 & 4 & 2 & 1 & 0 & 7 \\
$6 \sim 10$ 日 & 0 & 1 & 1 & 0 & 2 \\
1 ケ月以上 & 0 & 1 & 1 & 1 & 3 \\
\hline Total & 4 & 4 & 3 & 1 & 12 \\
\hline
\end{tabular}

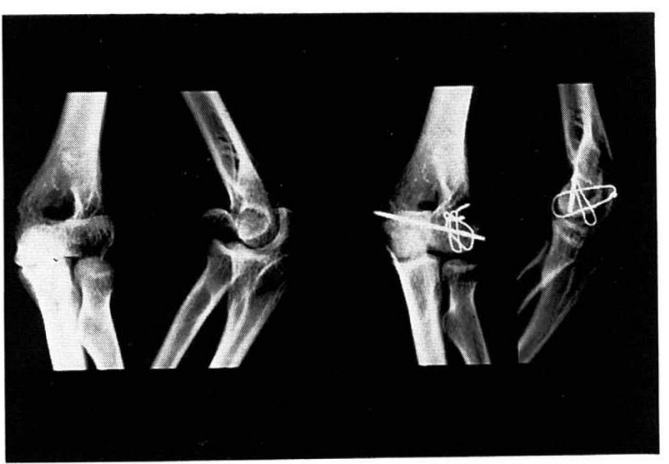

術前

術後

図 1 症例 344 才女性 B3-1-(3) 滑車型 受傷後 5 日目に threaded $\mathrm{K}$-wire 1 本と soft wire 2 本で固 定. 解剖学的に整復され，関節面に不整像は認められない。

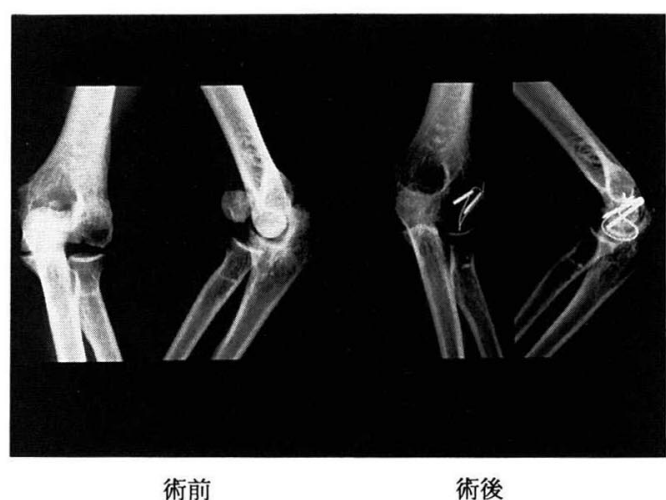

図 2 症例 8 49 女 女性 B3-1-（4）粉砕型 受傷後 10 日目に K-wire 2 本と soft wire 1 本で固定. 関節 面に軽度の骨欠損を認める。 
Excellent 4 例, Good 4 例, Fair 3 例, Poor 1 例で, 12 例中 8 例 $67 \%$ が Good 以上であった。骨折型によ る成績の違いはみられなかった，手術までの期間が長 いほど，成績は不良であった（表 3 ）。

代表症例を提示する.

症例 3.44 才, 女性. バイクで転倒し, 左时を打 撲した. 受傷後 5 日目に手術を行った．骨片は滑車の 一部を含む滑車型の骨折であり，さらに一部の骨軟 骨骨片を伴っていた，骨片を整復後， $1.5 \mathrm{~mm}$ の threaded K-wire にて前額面方向に固定し，軟鋼線に て矢状面方向に固定した. さらに骨軟骨片は軟鋼線に て締結した. 2 週間のシーネ固定の後, 自動運動を開 始した. 3 年 1 ケ月後の Grantham 評価は Excellent であった（図 1 ).

症例 8.49才, 女性. 階段から転落し, 左肘を打 撲した. 受傷後 10 日目に手術を行った. 2 つの骨片 を有する粉砕型で, threaded $\mathrm{K}$-wire 2 本と軟鋼線 1 本で固定した. 2 週間のシーネ固定の後, 自動運動 を開始した。 1 年 5 ケ月後, 时の ROM は伸展一 5 度, 屈曲 110 度で Grantham 評価は Good であった（図 2 ).

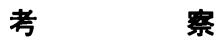

上腕骨小頭骨折の受傷機転は橈骨頭による剪断作用 により発生すると考えられているが，病歴を聞く限り 直達外力によることが多いように思われる.

本骨折の治療には保存方法と観血的方法があり，転 位のある骨片がある場合には観血的方法が一般的であ る. 観血的方法は骨片を切除するか観血的整復固定術 を行うかに意見が分かれる. 1975 年 Alvarez ${ }^{1)}$ は骨 片摘出術の成績が良いことを報告した. しかしその後, Collert $^{2)}$ や Grantham ${ }^{3)}$, 西島 ${ }^{4)}$ らは観血的整復固 定術の方が成績が優れていたと報告している。 また Grantham $^{3)}$ らは, 本骨折の不全型に対しては骨片摘 出術, 完全型に対しては徒手整復術または整復内固定
術（ORIF），滑車型に対してはORIF または骨片摘 出術, 粉砕型に対しては骨片摘出術が良いと述べてい る. 我々は 12 例中 11 例に ORIF を施行し, $\operatorname{good}$ 以 上の成績良好例は $64 \%$ （7例/11 例中）で新鮮例に限 れば 86\%（6 例/ 7 例中）が良好であった。骨片摘出 術は出来る限り避けるべきであり，可能な限り早期に 整復固定術を試みるべきであると考える.

固定方法に関しては最近内固定材料の開発も進み, Kirschner wire, AO micro screw, Herbert screw, 吸収ピン等が使用されている，我々は $\mathrm{K}$-wire にて前 額面を固定した後，軟鋼線にて矢状面をしっかりと固 定することにより強固な固定を得た。これは骨軟骨の スライス状不全骨折には特に有効であった. いずれの 方法を選択するにしても関節面を伴う上腕骨小頭骨折 の治療は基本的には解剖学的整復と強固な固定術を試 みるべきであり，小骨片あるいは粉砕骨折のため骨㾨 合が期待できない場合に骨片摘出の適応と考える.

$$
\text { ま と め }
$$

1.上腕骨小頭骨折 12 例の治療成績を検討した

2.ワイヤ締結法を利用して，すべての骨折型に対 する観血的整復内固定が可能であり，新鮮例では 86 \%で良好な結果が得られた。

3. 骨折型に関わらず，手術までの期間が長い症例 は予後不良となる傾向があった。

\section{参考文献}

1) Alvarez, E. et al. : Fracture of the capitulum humeri. J. Bone Joint Surg., 57-A : 1093-1096, 1975.

2) Collert, S. : Surgical management of fracture of the capitulum humeri., J. Bone Joint Surg., 48: 603-606, 1977.

3) Grantham, S. A. et al. : Isolated fracture of the fumeral capitellum. Clin. Orthop. 161 : 262-269, 1981.

4）西島雄一郎, 山崎安朗, 東田紀彦 : 上腕骨小頭骨折の 治療経験, 臨床整形外科, $21: 577-583,1986$. 